\title{
Phytochemical evaluation and in vitro antioxidant and photo-protective capacity of Calendula officinalis L. leaves
}

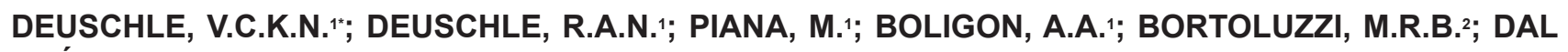
PRÁ, V.2; DOLWISCH, C.B.2; LIMA, F.O.2; CARVALHO, L.M.2; ATHAYDE, M.L. ${ }^{2}$

${ }^{1}$ Department of Industrial Pharmacy (Phytochemical Research Laboratory), Federal University of Santa Maria, Center for Health Sciences, Build 26, Room 1141, ZIP 97105-900, Santa Maria, RS, Brazil. ${ }^{2}$ Department of Chemistry (Analisys Chemistry Laboratory - Lachem), Federal University of Santa Maria, Build 17, Room 1438, ZIP 97105-900, Santa Maria, RS, Brazil. *Corresponding author: vivianenunes1@yahoo.com.br

\begin{abstract}
The plant Calendula officinalis $\mathrm{L}$. is widely applied due to its medicinal properties, which are mainly dermatological and ornamental. The goal of this study is to assess the phytochemical components in a hydroethanolic extract (HECO) from the leaves of Calendula officinalis L. using UV-VIS spectrophotometry and thin layer chromatography (TLC), as well as to identify and quantify the components related to its antioxidant capacity employing high performance liquid chromatographic (HPLC). The antioxidant capacity evaluation was performed using the DPPH method for superoxide and hydroxyl radicals. The photo-protective capacity was evaluated by UVspectrophotometry in order to determine the in vitro Sun Protection Factor(SPF). The results show the plant's strong antioxidant activity (DPPH and hydroxyl methods), which we believe to be related to the presence of flavonoids $(24.67 \mathrm{mg} / \mathrm{g})$, polyphenols $(33.90 \mathrm{mg} / \mathrm{g})$, condensed tannins $(27.30 \mathrm{mg} / \mathrm{g})$, and the amount of rutin $(37.25 \mathrm{mg} / \mathrm{g})$, and quercetin $(6.09$ $\mathrm{mg} / \mathrm{g}$ ) found during the study. The HECO presented a good antioxidant capacity, most likely due to the polyphenols, flavonoids, and tannins in its contents. However, the obtained SPF of 1.89 \pm 0.05 does not allow the plant to be classified as a stand-alone sunscreen, and more studies are needed in order to test its ability to enhance sunscreens in existing cosmetic formulations.
\end{abstract}

Keywords: Calendula officinalis. Marigold. Antioxidant. Phenolic Compounds. Photo-protection.

\begin{abstract}
RESUMO: Avaliação fitoquímica e capacidade antioxidante e fotoprotetora in vitro das folhas de Calendula officinalis L. A Calendula officinalis L. é uma planta amplamente utilizada por suas propriedades medicinais, principalmente dermatológica e ornamental. O objetivo deste estudo é avaliar constituintes fitoquímicos do extrato hidroetanólico das folhas de Calêndula officinalis L. (HECO) por espectrofotometria UV-visível e cromatografia em camada delgada (CCD), bem como detectar e quantificar os componentes relacionados com a capacidade antioxidante por Cromatografia Líquida de Alta Eficiência (CLAE). Posteriormente, foi avaliada a capacidade antioxidante pelo método do DPPH, radicais superóxido e hidroxila. Além disso, a capacidade fotoprotetora foi avaliada através de espectrofotometria UV para determinação do Fator de Proteção Solar in vitro (FPS). Os resultados evidenciaram que a planta apresentou uma excelente atividade antioxidante para o método do DPPH e do radical hidroxila, o que pode estar relacionada com a presença de flavonoides $(24,67 \mathrm{mg} / \mathrm{g})$, polifenóis $(33,90 \mathrm{mg} / \mathrm{g})$ e taninos condensados $(27,30 \mathrm{mg} / \mathrm{g})$ e da quantidade de rutina $(37,25 \mathrm{mg} / \mathrm{g})$ e quercetina $(6,09 \mathrm{mg} / \mathrm{g})$ encontrados neste estudo. O HECO apresentou uma notável capacidade antioxidante, provavelmente devido à presença de polifenóis, flavonoides e taninos. $\mathrm{O}$ valor do FPS encontrado $(1,89 \pm 0,05)$, não classifica a planta como um protetor solar isolado. No entanto, mais estudos são necessários para testar a capacidade de potencializar filtros solares em formulações cosméticas.
\end{abstract}

Palavaras-chaves: Calendula officinalis. Calêndula. Antioxidantes. Compostos fenólicos. Fotoproteção.

Recebido para publicação em 05/06/2014

Aceito para publicação em 10/11/2014

10.1590/1983-084X/14_055

Rev. Bras. PI. Med., Campinas, v.17, n.4, supl. I, p.693-701, 2015. 


\section{INTRODUCTION}

Calendula officinalis L., popularly known as "marigold" is a plant of interest for both its ornamental and medicinal properties. Belonging to the family Asteraceae, it is an annual plant that has been traditionally used in folk medicine as a remedy to treat various, mainly dermatological diseases (Wiktorowska et al. 2010). Its flowers have an orange-yellow colorant that is used in food, tea, and spice dye. Such dyes are also used in the preparation of ointments and cosmetics (Ercetin et al. 2012).

Among its constituents, phenolic compounds (flavonoids and phenolic acids), along with saponins, carotenoids, and triterpenic alcohols are presented (Parente et al. 2004; Butnariu \& Coradini, 2012). The flavonoids include quercetin, rutin, narcissin, isorhamnetin and kaempferol (Fonseca et al. 2010). Widely used in cosmetic formulations and in solar products due to its moisturizing properties, the extract of the flowers is also used to promote healing, and as an anti-inflammatory (Citadini-Zanette et al. 2012).

Studies conducted with different extracts of calendula have demonstrated anti-tumor, antiinflammatory, healing, and antioxidant properties (Fonseca et al. 2010; Agatonovic-Kurstin \& Loescher 2013). Also, considering the healing properties attributed to the plant, the angiogenic activity of ethanol extracts, hexanic, and dichlorometanic fractions of $C$. officinalis $L$. has been tested, and a positive effect on angiogenesis, inducing neovascularization was observed (Parente et al. 2011).

The antioxidant capacity of $C$. officinalis $L$. flower extract has been demonstrated in vitro by the DPPH method, and through UVB radiation exposure on the skin of mice (after oral administration), where skin protection was determined to be caused by glutathione (GSH) depletion prevention (Fonseca et al. 2010).

Topical formulations containing $4 \%$ or $5 \%$ of calendula essential oil applied before exposure to UVB radiation can protect the skin against damage, and prevent the formation of reactive oxygen species (Mishra et al. 2012). Polysaccharides isolated from Calendula officinalis ethanolic fraction have shown antitumor activity (Parente et al. 2004). The presences of lutein, lycopene, and xanthophylls, which contribute to anti-oxidant and anti-inflammatory effects, have also been described (Saini et al. 2012).

The objective of this work was to perform a phytochemical evaluation of hydroethanolic extract from the leaves of Calendula officinalis L., and to test its in vitro antioxidant and photoprotective capacity.

\section{MATERIALS AND METHODS \\ Plant collection and extraction}

Leaves of Calendula officinalis L. were collected in December 2012 in the city of Montenegro, Rio Grande do Sul, Brazil. Botanical identification was performed at the Department of Biology of the University of Cruz Alta - UNICRUZ, where a voucher specimen has been deposited as \#1097 in the Herbarium of Poisonous and Medicinal plants.

After removal of the flowers, the fresh leaves were divided roughly and dried in an oven with air circulation at $45^{\circ} \mathrm{C}$, for 3 days. The dried leaves were then reduced to powder in a knife mill. In order to eliminate lipophilic interferences, the powder was submitted to purification (prior to extraction) with $n$-hexane by means of maceration at room temperature for 7 days. After the removal of the $n$-hexane, the plant material was submitted to hydroethanolic extraction (ethanol - water 70:30, $\mathrm{V} / \mathrm{V}$ ), by maceration at room temperature during 7 days, with periodic shaking. Afterwards, the extraction liquid was filtered, and the ethanolic extraction described above was repeated. Reuniting both filtrates, they were concentrated under reduced pressure for ethanol removal, and then submitted to lyophilization until completely dry. The resulting product was named hydroethanolic extract of Calendula officinalis (HECO).

Analysis of alkaloids, terpenoids, saponins, and essential oil by thin layer chromatography (TLC)

Phytochemical screening was performed on the extracts in order to detect essential oil components, terpenoids, saponins, and alkaloids using TLC (Wagner \& Bladt 1996). The solid phase consisted in aluminum TLC plates coated with silicagel 60 with F254 fluorescent indicator. The mobile phases consisted in specific mixtures of solvents for each class of substances, (essential oils: toluene - ethyl acetate (93:7), terpenoids: ethyl acetate methanol - water $(77: 15: 8)$, saponins: chloroform glacial acetic acid - methanol - water $(64: 32: 12: 8)$, and alkaloids: toluene - ethyl acetate - diethylamine (70:20:10). Standards were applied for comparison. After elution, the results were observed under visible light, UV 254 and $365 \mathrm{~nm}$, and afterwards sprayed with specific indicators (essential oils: sulfuric anisaldehyde; terpenoids: sulfuric vanillin; saponins: sulfuric vanillin, and alkaloids: Dragendorff reagent).

Spectrophotometric analysis of polyphenols, flavonoids, and condensed tannins This analysis was performed on a Shimadzu UV-1201 spectrophotometer (Shimadzu, Kyoto, Japan).

Rev. Bras. PI. Med., Campinas, v.17, n.4, supl. I, p.693-701, 2015. 
The determination of phenolic compounds was performed using the Folin-Ciocalteau method, as described by Chandra \& De Meija (2004) with some modifications. For this, the sample was diluted to a concentration of $0.150 \mathrm{mg} / \mathrm{mL}$ in water, and added to $2 \mathrm{~mL}$ of sodium carbonate solution at 1.88 M. After 5 minutes, $0.5 \mathrm{~mL}$ of $2 \mathrm{~N}$ Folin-Ciocalteau was added. The solution was incubated for 10 minutes, and the absorbance was measured (in triplicate) in a spectrophotometer at a wavelength of $730 \mathrm{~nm}$. The total polyphenol content was expressed as milligrams of gallic acid equivalents (GAE) per gram of dry plant, based on the analytical curve of gallic acid in the following concentrations 0.001 , $0.01,0.02$ and $0.03 \mathrm{mg} / \mathrm{mL}(\mathrm{y}=30.767 x-0.0087$, $\mathrm{R}^{2}=0.9983$ ).

The total flavonoid content was established according to the method described by Woisky \& Salatino (1998). The sample was diluted to a concentration of $1 \mathrm{mg} / \mathrm{mL}$ in methanol. To $0.5 \mathrm{~mL}$ of sample was added $0.5 \mathrm{~mL}$ of aluminum chloride at $0.150 \mathrm{M}$, and $2.5 \mathrm{~mL}$ of methanol. After 30 minutes, the absorbance was read at $420 \mathrm{~nm}$. Tests were performed in triplicate, and for calculation of the assay standard curve, quercetin in the following concentrations of $12.5,25,50,100$, and $200 \mu \mathrm{g} / \mathrm{mL}$ $\left(y=0.0045 x-0.14, R^{2}=0.9997\right)$ was used. Levels of flavonoids were determined in milligrams of quercetin equivalents (QE) per gram of dry plant.

Tannins were determined using the method described by Morrison et al. (1995) with some modifications. The sample was diluted to a concentration of $25 \mathrm{mg} / \mathrm{mL}$ in methanol, and to $0.1 \mathrm{~mL}$ of sample was added $0.9 \mathrm{~mL}$ of methanol followed by $2.5 \mathrm{~mL}$ of vanillin solution $(0.065 \mathrm{M}$ in methanol), and $2.5 \mathrm{~mL}$ of a solution of hydrochloric acid $(2.25$ $\mathrm{M}$ in methanol). The solution was heated and kept at $60^{\circ} \mathrm{C}$ for 10 minutes, and the absorbance was determined at $500 \mathrm{~nm}$. Analyses were performed in triplicate. The total tannin content was expressed as milligrams of catechin equivalents (CE) per gram of dry plant, based on the standard curve of catechin in the following concentrations: $25,50,100,200$, and $300 \mu \mathrm{g} / \mathrm{mL}\left(\mathrm{y}=0.0015 \mathrm{x}-0.005, \mathrm{R}^{2}=0.9989\right)$.

\section{Identification and assay of quercetin and rutin using HPLC}

This experiment was performed using the method (slightly modified) described by Evaristo \& Leitão (2001). High performance liquid chromatography (HPLC-DAD) was performed with a Shimadzu, Kyoto, Japan; HPLC system, a Prominence Auto-Sampler (SIL-20A), equipped with Shimadzu LC-20 AT reciprocating pumps connected to a DGU $20 \mathrm{~A} 5$ degasser with a 20A CBM integrator, a DAD SPD-M20A UV-VIS detector, and LC Software solution 1.22 SP1. Reverse phase chromatographic analyses were carried out under gradient conditions using a $\mathrm{C}_{18}$ column Thermo Scientific ODS hypersil $(4.6 \mathrm{~mm} \times 250 \mathrm{~mm})$ packed with $5 \mu \mathrm{m}$ particles; the mobile phase A: water with acetic acid $0.33 \mathrm{M}$, and mobile phase B: methanol, and a composition gradient: $8 \%$ B until $5 \mathrm{~min}$, and then changed to obtain $20 \%, 30 \%, 50 \%, 60 \%, 70 \%$, $20 \%$, and $10 \%$ B at $20,30,40,50,60,70$ and 80 min, respectively, this following the method described by Silva et al. (2014) with slight modifications. The mobile phase was filtered through a $0.45 \mu \mathrm{m}$ membrane filter, and then degassed in an ultrasonic bath prior to use. Standard references solutions of quercetin and rutin were prepared in the HPLC mobile phase at a concentration range of 0.00625 $-0.250 \mathrm{mg} / \mathrm{mL}\left(\mathrm{y}=82431 \mathrm{x}-6151.4, \mathrm{R}^{2}=0.9975\right)$, and $0.0031-0.250 \mathrm{mg} / \mathrm{mL}\left(\mathrm{y}=96030 \mathrm{x}+7627.3, \mathrm{R}^{2}=\right.$ 0.9983 ), respectively. The marigold hydroethanolic extract was also dissolved in the mobile phase. All of the solutions and samples were first filtered through a $0.45 \mu \mathrm{m}$ membrane filter (Millipore). The chromatographic peaks were confirmed by comparing their retention times and Diode-ArrayUV spectra with those of the reference standards. Detected compounds were quantified at $327 \mathrm{~nm}$ and $356 \mathrm{~nm}$, respectively. The flow rate was 0.8 $\mathrm{mL} / \mathrm{min}$, and the injection volume was $40 \mu \mathrm{L}$. All chromatographic operations were carried out at ambient temperature, and in triplicate.

\section{Antioxidant capacity (In vitro) DPPH Method}

In order to evaluate the antioxidant capacity, the DPPH method was used, (2,2-diphenyl -1 picrylhydrazyl) (Choi et al. 2002) in concentrations of $250,125,62.5,31.25,15.62$ and $7.81 \mu \mathrm{g} / \mathrm{mL}$, dissolved in ethanol. To each $2.5 \mathrm{~mL}$ sample, $1 \mathrm{~mL}$ of $0.3 \mathrm{mM}$ DPPH solution dissolved in ethanol was added. After 30 minutes, the readings were taken in a spectrophotometer at $518 \mathrm{~nm}$. A solution of DPPH $(1 \mathrm{~mL}, 0.3 \mathrm{mM})$ dissolved in ethanol $(2.5 \mathrm{~mL})$ was used as a negative control. Ascorbic acid and rutin were used as standard (positive control), in the same concentration as the samples. Ethanol was used to zero the spectrophotometer, with the blank test solutions of each sample (without addition of DPPH) used to minimize interference from the components in a sample reading. The assay was performed in triplicate and the antioxidant capacity was calculated with the equation:

$\%$ Inhibition $=100-[($ Abs sample - Abs blank $) \times 100] /$ Abs control

Where: Abs sample is the absorbance of the test; Abs blank is the absorbance of the blank, and Abs control is the absorbance of DPPH solution in ethanol. 
The percentage DPPH inhibition was calculated, and a graph of percentage inhibition versus the concentration of the extract was plotted. The $I C_{50}$ calculation was performed using Microsoft Office Excel 2007 program, using the line equation of the standards and sample.

\section{Superoxide anion radical method $\left(\mathrm{O}_{2}^{--}\right)$}

Assessment of the ability to scavenge free radicals in relation to the superoxide radical is based on the generation of radical $\mathrm{O}_{2} \cdot \cdot$ throughout the system by enzymatic reaction, catalyzed by the enzyme hypoxanthine xanthine oxidase (Zhao et al. 2006). A sample (100 $\mu \mathrm{L})$ was added to the reaction solution containing $100 \mu \mathrm{L}$ of $30 \mathrm{mM}$ disodium ethylenediaminetetraacetic acid (EDTA), $100 \mu \mathrm{L}$ of $3 \mathrm{mM}$ hypoxanthine (HPX), and $200 \mu \mathrm{L}$ of $1.42 \mathrm{mM}$ nitrotetrazolium blue chloride (NBT). Afterwards, the solution was pre-incubated at ambient temperature for 3 minutes, and $100 \mu \mathrm{L}$ of $0.75 \mathrm{U} / \mathrm{mL}$ xanthine oxidase (XOD) was added to the mixture, with the volume being brought to $3 \mathrm{~mL}$ with $0.05 \mathrm{M}$ phosphate buffer $(\mathrm{pH} 7.4)$. The final solution was then incubated at ambient temperature for 40 minutes, and absorbance was measured at $560 \mathrm{~nm}$. The analyses were performed in triplicate. The activity of superoxide radical scavengers was calculated using the equation:

$\mathrm{O}_{2} \cdot \cdot$ capacity antioxidant $(\%)=\left[1-\left(\mathrm{S}-\mathrm{S}_{\mathrm{B}}\right) /\left(\mathrm{C}-\mathrm{C}_{\mathrm{B}}\right)\right] \times 100$

Where: $S, S_{B}, C$, and $C_{B}$ are absorbances of the sample, the background sample, control, and blank control groups, respectively.

\section{Hydroxyl radical method (HO)}

The antiradical activity studies of samples and analytical standards with the hydroxyl radical at different concentrations were performed using the 2-deoxy-D-ribose method proposed by Zhao et al. (2006) with some modifications. The $\mathrm{FeCl}_{3} \cdot 6 \mathrm{H}_{2} \mathrm{O}$ and ascorbic acid were prepared in milli-Q water before use. To a test tube, which underwent the reaction was added $100 \mu \mathrm{L}$ of the extract, $100 \mu \mathrm{L}$ of $1 \mathrm{mM}$ dissodium EDTA, $100 \mu \mathrm{L}$ of $1 \mathrm{mM} \mathrm{FeCl}_{3}$ - $6 \mathrm{H}_{2} \mathrm{O}, 100 \mu \mathrm{L}$ of 2-deoxy-D-ribose $36 \mathrm{mM} 100 \mu \mathrm{L}$ of $10 \mathrm{mM} \mathrm{H}_{2} \mathrm{O}_{2}$, and $100 \mu \mathrm{L}$ of L-ascorbic acid $1 \mathrm{mM}$ in $25 \mathrm{mM}$ phosphate buffer ( $\mathrm{pH}$ 7.4). Thereafter, the volume was completed to $1.0 \mathrm{~mL}$ with phosphate buffer. Then incubated at $37^{\circ} \mathrm{C}$ for $1 \mathrm{~h}$, the reaction was stopped by adding $1.0 \mathrm{~mL}$ of $10 \%$ trichloroacetic acid (TCA) (w/v), and $1.0 \mathrm{ml}$ of $1.0 \%$ thiobarbituric acid (TBA) $(\mathrm{m} / \mathrm{v})$ in phosphate buffer $(\mathrm{pH} 7.4)$. The mixture was then reheated in a water bath at $37^{\circ} \mathrm{C}$ for $15 \mathrm{~min}$. The samples were then cooled, and the final volume adjusted to $5.0 \mathrm{~mL}$ with deionized water, and the absorbance read at $532 \mathrm{~nm}$. The analyses were performed in triplicate. The antioxidant activity of the samples was calculated according to the equation below:

$\mathrm{OH} \cdot$ capacity antioxidant $(\%)=\left[1-\left(\mathrm{S}-\mathrm{S}_{\mathrm{B}}\right) /\left(\mathrm{C}-\mathrm{C}_{\mathrm{B}}\right)\right] \times 100$

Where, $S, S_{B}, C$, and $C_{B}$ are the absorbance of the sample, the sample blank, control, and blank control groups, respectively.

\section{Determination of the (in vitro) sun protection factor (SPF)}

To determine the SPF in vitro, calendula extract was dissolved in ethanol at a concentration of $0.2 \mu \mathrm{g} / \mathrm{mL}$. The sample was read at wavelengths from 290 to $320 \mathrm{~nm}$ (in increments of $5 \mathrm{~nm}$ ), in a spectrophotometer (Mansur et al. 1986) To calculate the FPS, the values of absorbance obtained in the range of 290-320 $\mathrm{nm}$ are multiplied by their respective values shown in Table 1 (developed by Sayre et al.,1979). The final sum is multiplied by 10 , according to the formula proposed by Mansur et al. (1986) and according to the equation:

$$
\operatorname{SPF}(\text { spectrometry })=\operatorname{CF} \times \sum_{220}^{320} \mathrm{EE}(\lambda) \times I(\lambda) \times \text { abs }(\lambda)
$$

Where CF $=$ correction factor $(=10)$, determined in accordance with two known SPF sunscreens such that a cream containing $8 \%$ resulted in SPF 4 homosalate; EE $(\lambda)=$ erythemogenic effect radiation wavelength $(\lambda)$; I $(\lambda)=$ intensity of the sunlight at a wavelength $(\lambda)$; abs $(\lambda)=$ sample absorbance at wavelength $(\lambda)$.

The values of EE $(\lambda)$ and I $(\lambda)$ were calculated as previously by Sayre et al. (1979) as described in Table 1.

\section{Statistical analysis}

The results of the determinations were subjected to analysis of variance (ANOVA) followed by post hoc multiple comparison Tukey test ( $p$ $\leq 0.05$ ). The analysis was performed using the Windows Excel 2010 program.

TABLE 1. Erythemogenic effect relationship $(E E)$ versus radiation intensity $(I)$ according to the wavelength $(\lambda)$.

\begin{tabular}{cc}
\hline$\lambda(\mathrm{nm})$ & EE $\times$ I (normalized) \\
\hline 290 & 0.0150 \\
295 & 0.0817 \\
300 & 0.2874 \\
305 & 0.3278 \\
310 & 0.1864 \\
315 & 0.0839 \\
320 & 0.0180 \\
\hline
\end{tabular}




\section{RESULTS}

Qualitative analysis of the HECO by TLC determined the presence of alkaloids, terpenoids, saponins, and volatile oils.

The determinations of total amounts of polyphenols, flavonoids and tannins of HECO are shown in Table 2 (analytical curve gallic acid: $y=30.767 x-0.0087, R^{2}=0.9983$; quercetin: $y=0.0045 x-0.14, R^{2}=0.9997$, and cathequin: $\left.y=0.0015 x-0.005, R^{2}=0.9989\right)$. Rutin and quercetin were detected and quantified in the HECO by HPLC (Figure 1) (analytical curve rutin: $y=82431 x-6151.4$, $\mathrm{R}^{2}=0.9975$, and quercetin: $\mathrm{y}=96030 \mathrm{x}+7627.3$, $\left.\mathrm{R}^{2}=0.9983\right)$. The antioxidant capacity (DPPH method) is demonstrated in Figure 2. The inhibitory concentration $\left(\mathrm{IC}_{50}\right)$ was calculated in comparison with ascorbic acid and rutin. For ascorbic acid, the IC $_{50}$ value was $16.57 \mu \mathrm{g} / \mathrm{mL}$, for rutin it was 6.25 $\mu \mathrm{g} / \mathrm{mL}$, and for HECO it was $5.86 \mu \mathrm{g} / \mathrm{mL}$. Results of antiradical activity against the hydroxyl radical and the superoxide anion are show in the Table 3. The SPF result was $1.89 \pm 0,05$.

\section{DISCUSSION}

Our qualitative analysis with TLC determined the presence of alkaloids, terpenoids, saponins, and volatile oils in the HECO. Previously, other works had identified that the flowers of $C$. officinalis contain
TABLE 2. Spectrophotometric assay for determining total polyphenols, flavonoids, and tannins of HECO.

\begin{tabular}{cc}
\hline $\begin{array}{c}\text { Secondary } \\
\text { metabolite }\end{array}$ & Amount \pm SD \\
\hline Polyphenols & $33.90 \mathrm{mg}$ of GAE/g extract \pm 0.07 \\
Flavonoids & $24.67 \mathrm{mg}$ of QUE/g extract \pm 0.40 \\
Condensed tannins & $27.30 \mathrm{mg}$ of CE/g extract \pm 1.48
\end{tabular}

GAE (gallic acid equivalent), QUE (quercetin equivalent), CE (catechin equivalent). The results are the mean \pm SD of three experiments. HECO (Hydroethanolic extract of $C$. officinalis $L$. leaves) $(n=3)$.

saponins and terpenes (Citadini-Zanette et al. 2012; Hamburger et al. 2003).

The HECO showed $33.90 \mathrm{mg} / \mathrm{g}$ of total polyphenols, $24.67 \mathrm{mg} / \mathrm{g}$ of total flavonoids and $27.30 \mathrm{mg} / \mathrm{g}$ of condensed tannins. According to Fonseca et al. (2010), the extract of marigold flowers presented amounts of $28.6 \mathrm{mg} / \mathrm{g}$ of total polyphenols (gallic acid equivalents), and $18.2 \mathrm{mg} / \mathrm{g}$ of total flavonoids (quercetin equivalents). Therefore, the results obtained by the HECO in the present work were higher than those of the literature.

The flowers of $C$. officinalis are well known
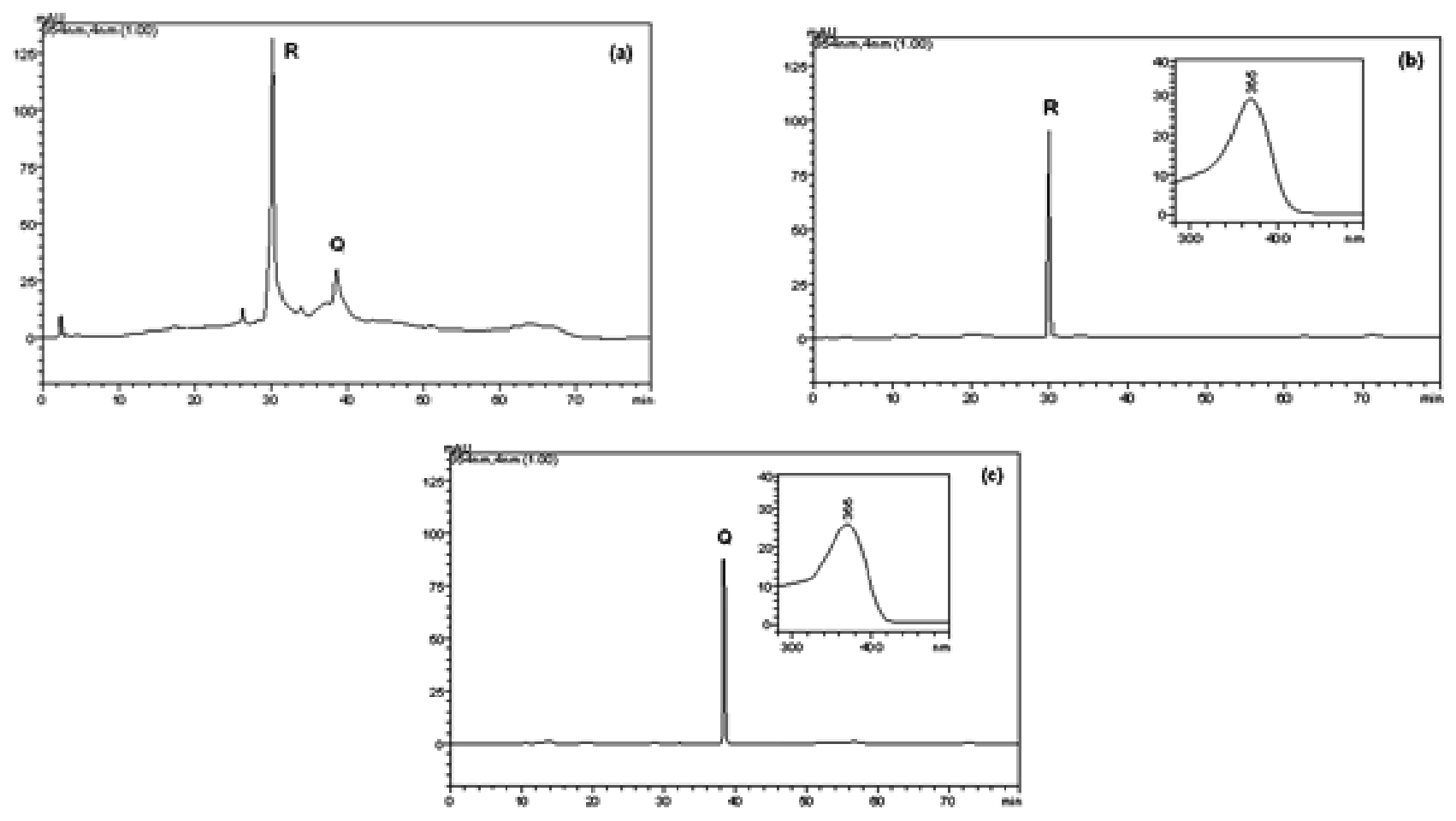

FIGURE 1. (a) Chromatogram of rutin (R) and quercetin (Q) quantification in HECO (Hydroethanolic extract of Calendula officinalis $\mathrm{L}$. leaves); (b) chromatogram and spectrum of standard rutin (R) and (c) chromatogram and spectrum of standard quercetin $(Q) .(n=3)$. 


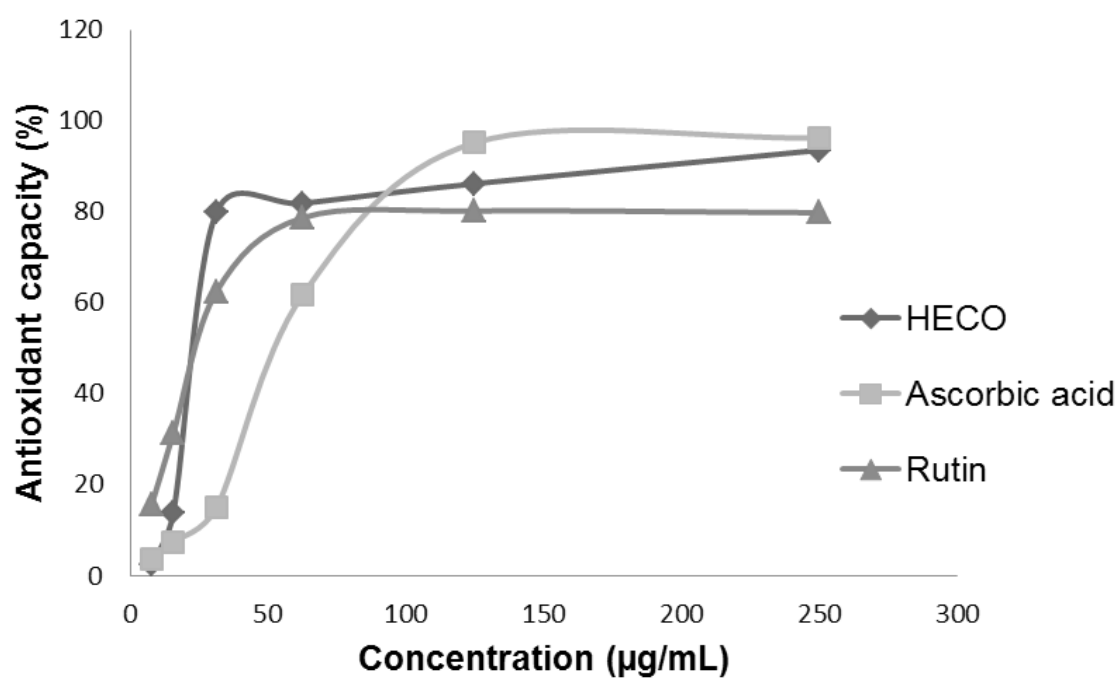

FIGURE 2. Antioxidant capacity of HECO (Hydroethanolic extract of Calendula officinalis L. leaves), ascorbic acid, and rutin standard, evaluated by the DPPH method. (ANOVA, Tukey test, $p>0.05)$. $(n=3)$.

TABLE 3. Antioxidant capacity by hydroxyl radical method, and superoxide anion radical of the HECO.

\begin{tabular}{ccc}
\hline HECO $(\mu \mathrm{g} / \mathrm{mL})$ & $\begin{array}{c}\text { Hydroxyl Radical }(\%) \\
\pm \text { SD }\end{array}$ & $\begin{array}{c}\text { Superoxide Anion Radical (\%) } \\
\text { SD }\end{array}$ \\
\hline 250 & $76.05 \pm 2.67$ & $4.27 \pm 0.94$ \\
125 & $71.00 \pm 0.89$ & $2.54 \pm 0.98$ \\
62.5 & $66.60 \pm 8.02$ & $6.64 \pm 2.38$ \\
31.25 & $61.24 \pm 1.33$ & $7.13 \pm 0.22$ \\
15.62 & $39.18 \pm 3.12$ & $6.94 \pm 1.42$ \\
7.81 & $26.26 \pm 0.89$ & $6.81 \pm 1.82$ \\
\hline
\end{tabular}

The results are the mean \pm SD of three experiments. HECO (Hydroethanolic extract of Calendula officinalis L. leaves) $(n=3)$.

for their anti-inflammatory, antipyretic, antitumor, and healing effects (Saini et al. 2012; Bortoldo et al. 2009) as well as antioxidant activity (Shivasharan et al. 2013). These activities are related to the chemical composition of the plant, especially the presence of flavonoids and polyphenols (Butnariu \& Coradini 2012; Borella et al. 2010). According to the results obtained for the HECO, a potential antioxidant and anti-inflammatory effect is also exhibited. Using leaves provides the advantage of obtaining a greater quantity of plant material than the quantity obtained with flowers, and hence a greater amount of extract for processing, optimizing, and thereby preparing. Determining tannins, we found a concentration of $27.30 \mathrm{mg} / \mathrm{g}$. A concentration of 6-10\% tannin concentration in marigold flowers has been reported but its presence in the leaves has not been evaluated ( $R e$ et al. 2009). Due to the scarcity of data in the literature regarding the determination of condensed tannins from the leaves of HECO, this is an important result, since it is known that tannins are secondary plant metabolites responsible for anti-inflammatory, antimicrobial, and free radical scavenging activity, among others (Simões et al. 2010), and it may be related to the good results obtained when determining antioxidant capacity in this study.

Rutin $37.25 \mathrm{mg} / \mathrm{g}$, and quercetin 6.09 $\mathrm{mg} / \mathrm{g}$ were detected and quantified in the HECO with HPLC. Rutin is known for having antiplatelet, antiviral, antihypertensive (Lee et al. 2012; Li et al. 2012), and antioxidant effects (Hubinger et al. 2010), and is used for venous and lymphatic insufficiency, capillary fragility (Baby et al. 2008), and also as a protector against solar damage (Velasco et al. 2008). Quercetin is a flavonoid that occurs naturally in plants, with important effects on oxidative stress (Prince et al. 2012). Its high antioxidant activity in plants and foods is proven (Luehring et al. 2011). Thus, the presence of quercetin and rutin in the HECO relates to its antioxidant activity, which was previously described by Olennikov \& Kashchenko, 2014 and Pacheco et al., 2011.

Antioxidant capacity was evaluated using the DPPH method, which is a stable free radical, used as substrate, which produces a violet colored 
solution. In the presence of antioxidants, the color of the solution (as reduction occurs), ranges from violet to yellow (Iha et al. 2008; Jothy et al. 2011). In this study, HECO exhibited excellent antioxidant capacity, similar to the rutin standard. There were no significant differences between HECO and standard $(p>0.05)$.

It is known that phenolic compounds can display antioxidant activity due to their chemical structures, and that they play an important role in the capture and neutralization of free radicals. A substance with antioxidant properties is able to retard or inhibit oxidation of the substrate even at low concentrations (Sousa et al. 2007). Thus, the HECO, which for the lowest concentration assayed $(7.81 \mu \mathrm{g} /$ $\mathrm{mL}$ ) gave a DPPH inhibition of $79.84 \%$, exhibited an excellent in vitro antioxidant capacity. With the same concentration, ascorbic acid showed an inhibition of $14.93 \%$, and rutin showed an inhibition of $62.44 \%$. According to Jothy et al. (2011), and Sousa et al. (2007), the percentage of antioxidant capacity for this method is proportional to the amount consumed by $\mathrm{DPPH}$, and the greater this percentage, the greater the ability of the sample in scavenging free radicals. The inhibitory concentration ( $\left.\mathrm{IC}_{50}\right)$ corresponds to the lowest concentration of the tested sample capable of causing a corresponding inhibition (Jothy et al. 2011; Sousa et al. 2007), and was determined using the standard line equation. The $\mathrm{IC}_{50}$ values were 16.57 $\mu \mathrm{g} / \mathrm{mL}$ for ascorbic acid, $6.25 \mu \mathrm{g} / \mathrm{mL}$ for rutin, and $5.86 \mu \mathrm{g} / \mathrm{mL}$ for HECO.

Phenolic compounds, Maillard reaction products, and sulfites are principle endogenous antioxidants (Zhao et al. 2006). Among the phenolic compounds, tannins and flavonoids stand out for their well-known antioxidant and antiradical activities. Due to the presence of these compounds in the HECO, we employed the superoxide anion radical $\left(\mathrm{O}_{2}^{--}\right)$, and hydroxyl radical (HO) methods. The results indicate clear antiradical activity against the hydroxyl radical. The $31.25 \mu \mathrm{g} / \mathrm{mL}$ concentration of the extract showed an inhibition of $61.24 \%$. The ability to isolate hydroxyl radicals is important, because these radicals are related to lipid peroxidation (Zhao et al. 2006). The antiradical activity against the superoxide anion was low, and indicated that the plant has no useful activity against this radical.

Sunscreens are substances used in photoprotective formulations, and they can be classified as organic or inorganic. Organic filters can be either natural or synthetic, and are capable of absorbing ultraviolet radiation (Galano et al. 2010). One of the current trends in cosmetology is the development of products with the greatest degree of natural ingredients possible. Thus, in this study we evaluated the in vitro photoprotective capacity in the $\mathrm{HECO}$, in order to use it in cosmetic formulations.
It has been previously demonstrated that plant extracts used in cosmetic and pharmaceutical formulations have the ability to absorb ultraviolet light (Polonini et al. 2011). Any substance, to be considered a sunscreen, must display an SPF of higher than 2 (Violante et al. 2009). The result of $1.89 \pm 0,05$, for the SPF demonstrates that this plant is not a sunscreen by itself (Brasil, 2002), Yet compared to results obtained from other plant extracts, such as those reported by Polonini et al (2011), where Macrosiphonia velame extract showed an in vitro SPF of 0.36 , this HECO value is considerably high. This suggests that HECO could be used in combination with synthetic sunscreens to enhance their protective effect. The HECO showed remarkable antioxidant activity when using both the DPPH and hydroxyl radical methods. The results may well have occurred due to the presence of flavonoids and polyphenols in the plant. The presence of condensed tannins and the rutin and quercetin detected may also have contributed to this activity. The photoprotective capacity measured reveals that while the plant cannot be used alone as sunscreen, further studies would determine the possibility of its use as a synthetic sunscreen potentiator.

\section{REFERENCES}

AGATONOVIC-KURSTIN, S.; LOESCHER, C.M. Qualitative and quantitative high performance thin layer chromatography analysis of Calendula officinalis using high resolution plate imaging and artificial neural network data modeling. Analytica Chimica Acta, v. 798, p.103-108,2013.

BABY, A.R. et al. Estabilidade e estudo de penetração cutânea in vitro da rutina veiculada em uma emulsão cosmética através de um modelo de biomembrana alternativo. Brazilian Journal of Pharmaceutical Science, v. 44, n.2, p.235-248, 2008.

BORELLA, J.C. et al. Avaliação da espalhabilidade e do teor de flavonoides em forma farmacêtica semissólida contendo extratos de Calendula officinalis L. (Asteraceae). Revista de Ciências Farmacêuticas Básica e Aplicada, v.31, n.2,p.193-197, 2010.

BORTOLDO, D.P.G. et al. Teor e rendimento de flavonóides em calêndula (Calendula officinalis L.) cultivada com diferentes lâminas de irrigação. Revista Brasileira de Plantas Medicinais, v.11, n.4, p.435441, 2009.

BRASIL. 2002. Resolução RDC n. 237 de 02 de agosto de 2002. Diário Oficial da União, Brasília, Brazil, 26 agosto, 2002.

BUTNARIU, M.; CORADINI, C.Z. Evaluation of biologically active compounds from Calendula officinalis flowers using spectrophotometry. Chemistry Central Journal, v. 6, p.35, 2012.

CHANDRA, S.; De Mejia, E.G. Polyphenolic compounds, antioxidant capacity and quinonereductase activity of an

Rev. Bras. PI. Med., Campinas, v.17, n.4, supl. I, p.693-701, 2015. 
aqueous extract of Ardisiacompressa incomparision to mate (Ilex paraguaiensis) and green (Camellia sinensis) teas. Journal of Agricultural and Food Chemistry, v.52, p.3583-3589, 2004.

CITADINI-ZANETTE, V. et al. Calendula officinalis L. (Asteracea) : Aspectos botânicos, ecológicos e usos. Visão Acadêmica, v.13, n.1, p.6-23, 2012.

CHOI, C.W. et al. Antioxidant activity and free radical scavenging capacity between Korean medicinal plants and flavonoid by assay-guided comparision. Plant Science, v.163, n.6, p.1161-1168, 2002.

ERCETIN, T. et al. Comparative assessment of antioxidant and cholinesterase inhibitory properties of the marigold extracts from Calendula arvensis L. and Calendula officinalis L. Industrial Crops and Products, v.36, n.1, p.203-208, 2012.

EVARISTO, I.M.; LEITÃO, M.C.. Identificação e quantificação por DAD-HPLC, da fração fenólica contida em folhas de Quercus súber L. Silva Lusitana ,v.9, n.2, p.135-141, 2001.

FONSECA, Y.M. et al. Protective effect of Calendula officinalis extract against UVB-induced oxidative stress in skin : Evaluation of reduced glutathione levels and matrix metalloproteinase secretion. Journal of Ethnopharmacology, v.127, n.3, p.596-601, 2010.

GALANO, A. et al. Carotenoids can act as antioxidants by oxidizing the superoxide radical anion. Physical Chemistry Chemistry Physical, v.12, n.1, p.193-200, 2010.

HAMBURGER, M. et al.Preparative purification of the major anti-inflammatory triterpenoid esters from Marigold (Calendula officinalis). Fitoterapia, v.74, n.4, p.328-338, 2003.

HUBINGER, S.Z. et al. Dimorphandra mollis : uma alternativa como fonte de flavonoides de ação antioxidante. Latin American Journal of Pharmacy, v.29, n.2,p. 271-274, 2010.

IHA, S.M. et al. Estudo fitoquímico de goiaba (Psidium guajava L.) com potencial antioxidante para o desenvolvimento de formulação fitocosmética. Brazilian Journal of Pharmacognosy, v. 18, n.3, p.387-393, 2008.

JOTHY, S.L. et al. Phytochemicals screening, DPPH free radical scavenging and xanthine oxidase inhibitiory activities of Cassia fistula seeds extract. Journal of Medicinal Plants Research, v.5, n.10, p.1941-1947, 2011.

LEE, W. et al. Barrier protective effects of rutin in LPSinduced inflammation in vitro and in vivo. Food and Chemical Toxicology, v. 50, n.9, p.3048-3055, 2012.

LI, F. et al. Optimisation of infrared-assisted extraction of rutin from crude flos Sophoraeim maturus using response surface methodology and HPLC Analysis. Phytochemical Analysis, v. 23, n.4, p.292 - 298, 2012.

LUEHRING, M. et al. Vitamin E-sparing and vitamin E-independent antioxidative effects of the flavonol quercetin in growing pigs. Animal Feed Science and Technology, v. 169, p.199-207, 2011.

MANSUR, J.S. et al. Determinação do fator de proteção solar por espectrofotometria. Anais Brasileiros de Dermatologia, v. 61, n.3, p.121-124, 1986.

MISHRA, A.K. et al. Effects of calendula essential oilbased cream on biochemical parameters of skin of albino rats against ultraviolet $B$ radiation. Scientia Pharmaceutica, v. 80, n.3, p. 669-683, 2012.

MORRISON, I.M. et al. Determination of Lignin and Tannin contents of cowpea seeds coats. Annals of Botany, v. 76, p.287-290, 1995.

OLENNIKOV, D.N.; KASHCHEENKO, N. I. Componential profile and amylase inhibiting activity of phenolic compounds from Calendula officinalis L. Leaves.The Scientific World Journal, v. 2014, p. 1-9, 2014.

PACHECO, A. C. et al.Deficiência hídrica e aplicação de ABA nas trocas gasosas e no acúmulo de flavonoides em calêndula (Calendula officinalis L.). Acta Scientiarum. Agronomy, v. 33, n. 2, p. 275-281, 2011.

PARENTE, M. et al. Pharmacognostic analysis of the dust and evaluation of the effect of the ethanolic extract of the flowers of Calendula officinalis L. cultivated in Brazil in the immune system. Revista Eletrônica de Farmácia, v.1, p.9-16, 2004.

PARENTE, L.M.L. et al. Angiogenic activity of Calendula officinalis flowers L. in rats. Acta Cirurgica Brasileira, v.26, n.1, p.19-24, 2011.

POLONINI, H.C. et al. Fotoprotetores naturais como instrumento de ação primária na prevenção de câncer de pele. Revista APS, v.14, n.2, p.216-223, 2011.

PRINCE, P. et al. Protective effects of quercetin on mitochondrial oxidative stress in isoproterenol induce myocardial infarcted rats : an in vivo and in vitro study. Food Research International, v.49, n.1, p.233-241, 2012.

RE, T.A. et al. Application of the threshold of toxicological concern approach for the safety evaluation of calendula flower (Calendula officinalis) petals and extracts used in cosmetic and personal care products. Food and Chemical Toxicology, v.47, n.6, p.1246-1254, 2009.

SAINI, P. et al. Effects of Calendula officinalis on human gingival fibroblasts. Homeopathy, v.101, n.2,p.92- 98, 2012.

SAYRE, R. M. et al. Comparison of in vivo and in vitro testing of sunscreening formula. Photochemistry and Photobiology, v. 29, n.3, p.559-566, 1979.

SHIVASHARAN, B.D. et al.Protective effect of Calendula officinalis L. flowers against monosodium glutamate induced oxidative stress and excitotoxic brain damage in rats. Indian Journal of Clinical Biochemistry, v.28, n.3, p.292-298, 2013.

SILVA, A.R.H. et al. Biochemical and hematological effects of acute and sub-acute administration to ethyl acetate fraction from the stem bark Scutia buxifolia Reissek in mice. Journal of Ethnopharmacology, v.153, n.3, p. 908-916, 2014.

SIMÕES, C.M.O. et al. Farmacognosia, da planta ao medicamento. 6 ed. Porto Alegre : Editora UFRGS, 2010, 1102p.

SOUSA, C.M.M. et al.Fenóis totais e atividade antioxidante de cinco plantas medicinais. Química Nova, v. 30, n.2, p.351-355, 2007.

VELASCO, M.V et al. Associação da rutina com p-metoxicinamato deoctila e benzofenona-3: avaliação in vitro da eficácia fotoprotetora por espectrofotometria de refletância. Latin American Journal of Pharmacy, v.27, n. 1, p.23-27, 2008.

VIOLANTE, I.M.P. et al. Avaliação in vitro da atividade fotoprotetora de extratos vegetais do cerrado de Mato

Rev. Bras. PI. Med., Campinas, v.17, n.4, supl. I, p.693-701, 2015. 
Grosso. Brazilian Journal of Pharmacognosy, v. 19, n.2a, p. 452-457, 2009.

WAGNER, H.; BLADT, S. Plant Drug Analysis. 2ed., Berlim: Springer-Verlag, 1996. 384p.

WIKTOROWSKA, E. et al. Significant enhancement of oleanolic acid accumulation by biotic elicitors in cell suspension cultures of Calendula officinalis L. Enzyme and Microbial Technology, v.46, n.1, p.14-20, 2010.
WOISKY, R.G.; SALATINO, A. Analysis of própolis : some parameters and procedures for chemical quality control. Journal of Apicultural Research, v.37, n.2, p.99-105, 1998.

$\mathrm{ZHAO}, \mathrm{H}$. et al. Effects of extraction solvent mixtures and antioxidant activity evaluation and their extraction capacity and selectivity for free phenolic compounds in barley (Hordeum vulgare L.). Journal of Agricultural and Food Chemistry, v.54, n.19, p.7277-7286, 2006. 